\title{
Brutal Effects of Online Game in Animator Perspective
}

\author{
Irwan Sarbeni* \\ Film and Television Study Program \\ Universitas Pendidikan Indonesia \\ Bandung, Indonesia \\ *irwansarbeni@upi.edu
}

\begin{abstract}
According to a study of the news in the mass media, it is known that many online games contribute a negative impact on the attitude or behavior of its addict, even up to the brutal or fatal level both for himself and what he does to others. Adverse effects of playing online games that are difficult to control even categorized as a mental illness by WHO. When cases of deviant behavior rooted in online games are brought to the surface, these cases are often discussed as social, psychological, parenting, educational, law, and other issues without ever being revealed or questioned from the perspective of online games themselves as animation products. The writing of this article aims to discuss the results of a study on the issue of the online game's brutal effects on gamers from the animator's perspective. This research uses a descriptive qualitative approach with the main data from interviews with several animation experts, and studies of the literature written by animators recommended by the experts. The result of this study explains that the worst effect of games that can be revealed within the reach of the animator's sight is that the consequence of game addiction may be experienced by gamers. Animators recognize that opium can be triggered by the quality of games that are attractive and provide virtual satisfaction. The quality itself would not have resulted unless the animator carefully applies the principles of animation design. Whereas for issues that go further than the opium such as the brutal effects of online gaming are problems that are beyond the animator's capacity to explain. The animator's perspectives and epistemology cannot be forced to reveal the case further unless by collaborating with experts from inter-disciplines.
\end{abstract}

Keywords—brutal effect, online game, animation, animators

\section{INTRODUCTION}

November 2, 2019, a young man with the initials FP, was arrested by the police over a report of the murder of Ahsanul Fauzi (31), an online taxi driver. The victim was killed with a number of cutter knife stabs in the neck when the perpetrators staged an attempted robbery of money against victims who were ultimately found to have failed. The victim was found died a few moments later by the Bank Rakyat Indonesia (BRI)'s security Harjasari unit. As quoted from Sudarno [1], the murder took place in the early hours of October 31, 2019 in front of the BRI Bank Harjasari office, Jalan Raya Wangun, East Bogor District, Bogor City. Based on police investigation, it was found that the FP deliberately planned a robbery in order to get money to repair his laptop so that he could return to playing online games. FP is a heavy addict of online games, Kasat Reskrim (Head of Criminal Investigation Unit) Polresta Bogor said that since childhood FP had been addicted to online games, this statement was also strengthened by his family. It has been two years since FP has also lived nomadic to allow him continue playing games.

The FP case was not the first time happened in criminal history. Throughout 2019, there have been a number of murder cases occurring over the issue of online gaming. Among them, in Tangerang, last May 8, the domestic violence that led to death was executed by DS (24) to his wife for he used to be disturbed while playing online games [2]. In Belagavi, Karnataka, India, September 8, a 25-year-old man, RK, kill and mutilate his father for he was asked to stop playing PUBG [3]. And, in Palmerah, West Jakarta, September 27, a man, MA, 23 years old, kill his uncle after being reprimanded for playing the online game Mobile Legend [4]. Aside from the homicide cases, there were even more cases of disorder and other crimes that occurred due to online gaming problems, including the case of a husband divorcing his wife [5]; wife who divorced her husband [6]; abandoned children to death [7]; abandoned wife who was pregnant [8]; attempted to poison parents [9]; students who sold their school library assets [10]; elementary students who skipped school for 4 months [11]; died from staying up late for playing all day online games [12]; committed suicide for releasing the opiate to the games [13] burning classmates, to suicide in honor of the hero in his online game [7]

All these crimes and disorders clearly illustrate how easy it is for someone to lose their mind, lose self-control, to lose one's life just for the sake of their beloved online game. In fact, because of the problem urgency caused by game addiction, on June 18, 2018 WHO officially designated Game Addiction or Game Disorder as a modern mental disorder caused by habit or addiction [14]. Also summarized from Science Alert [14], game addiction can be called a disease if it fulfills three things. First, lacks control over their gaming habits, second, prioritizes gaming over other interests and activities, and the third, continues gaming despite its negative consequences. The WHO 
said all three of these must occur or be seen within a year before a diagnosis is made. In addition, WHO said the games here include various types of games played alone or multiplayer, both online and offline. However, this does not mean that all types of games are addictive and can cause distraction. Playing games is considered a mental disorder only when the games interfere with or damage personal, family, social, work and educational lives, according to the WHO. In its portal, WHO also added that there are a quite a lot of evidence to suggest game addiction can cause health problems.

Of the 10 publications on the internet that discuss the issue of opium online games in the last 3 years and 10 scientific articles that are sampled as literature studies in this study, almost all of them relate the phenomenon and its impacts to psychological, medical, sociological, law, counseling, educational, or communication issues. The existing discourse and research have focused more on these fields without one ever specifically heeded from an animation perspective as if there is nothing at all problematic about the aspect of animation or video games which became the gamers addiction object. In the perspective of animation, these cases are certainly seen as serious and fatal problems. Arif asserted (in the interview, 2020), in terms of their use to the public, animation can be loaded certain messages in accordance with the interests of its use, even can have an effect on changing the behavior of its gamers. This means that in addition to the mental level of gamers, the problem root could also come from the animation or the video game itself, without the game there would be no game addiction. Therefore, the purpose of this study is to discuss the results of a study on the issue of the online games' brutal effects on gamers from the animator's perspective.

\section{LITERATURE REVIEW}

In previous research, Musthafa [15] emphasized that online games can indeed have negative impacts on children. Number of current online games shows scenes or acts of violence that would potentially become bad examples and lead to the development of bad behavior in the children who play them. According to him, the bad consequences of playing online games can actually be minimized with the role of parental supervision. Mustafa's research seeks to study the effect of the intensity of playing online games and parental supervision on children's aggressive behavior. The study involved 50 respondents with an age range of 10-14 years. Based on the results of this study, it was revealed that the higher the intensity of playing online games, the higher the child's aggressive behavior, but the aggressiveness would be mitigated by parental supervision.

In another study, Siregar [16] also analyzed the effect of the level of playing video games with violence scene on the level of adolescent aggressive behavior. Siregar also analyzed the influence of personal and situational factors as forming behavior to play violent video games on the level of adolescent aggression behavior. The results showed that the higher the intensity of playing violent video games, the higher the level of adolescent aggressiveness. Siregar also reported that male respondents tended to have a higher intensity of playing violent video games than female one.
Although the two studies above do not detail what the output of aggressive behavior from the game addicts they studied, from the research description of both - supported by 10 samples of internet publications and 10 journals as mentioned in the background - it is quite understandable that online games can indeed create bad impact for the addicts.

In line with what the author has described in the background, in the description of the two studies above, there is no mention of any problems in the online game itself. Musthafa limits his research to the relationship between the aggressiveness of gamer behavior and parental supervision from a parenting point of view, while Siregar, through her psychological perspective, focuses on mapping individual situations that affect their behavioral aggressiveness due to playing video games. Therefore, by the implementation of this research, it is hoped that the reader will be able to find out what the animators think about these problems and how their epistemology can explain it.

\section{METHODS}

This research will be presented in a qualitative descriptive form. According to Gunawan [17], the qualitative method seeks to understand and interpret the meaning of an event of human behavior interaction in certain situations according to the researcher's own perspective. Research that uses qualitative research aims to understand the objects under study in depth. Likewise, in this study, the author seeks to offer an animator's perspective in understanding and uncovering events of fatal behavioral deviations due to online games. Through this perspective it is hoped that new facts about the role or effect of visualization on online games will be revealed in influencing the destructive behavior of gamers.

The data collection process in this study will begin with an interview. Referring to the statement of Tharenou, Donohue, \& Cooper [18], interviews and questionnaires are usually carried out to find out, confirm, or confirm people's opinions and prejudices towards problems, events, behavior, and so on. According to Tharenou this technique can be used in any research model and can be used as the main data collection technique. In accordance with the focus, this study really demands the thoughts or opinions of animation experts or online game experts to gain theoretical understanding and explanation from the perspective of animation behind gaming disorder events and behavioral deviations due to online games.

Interview data will be used as a reference to find relevant literature in accordance with the trend of perspectives or recommendations from experts. The researcher then summarizes the animator's perspective in his literature. In addition, this literature will also guide researchers in dissecting the potential effects of gaming and drawing conclusions.

\section{RESUlt AND DisCUSSION}

\section{A. Animator's Perspective}

According to animation experts' opinion, animation is a science that addresses technical issues. When animators are faced with disorder problems that arise as a consequence of playing online games, all they could speak are limited only 
until the technical problems of making and operating the online game. As for the effects of deviant behavior that it might cause, this has entered into other areas of discussion, such as psychology, communication, or other scientific areas. Even if the animator must participate in uncovering or finding solutions to the cases of disorder that occur, animators would have collaborated with experts from interdisciplines.

For animators, the aim of making online games is only to the point of entertainment. According to Irvan (in an interview, July 2020), one of the speakers who is an animation expert, in making a game, animators are also bound by social norms and moral responsibility. No animator deliberately makes online games for criminal purposes, for if so, then the products they made will be devoid of enthusiasts or gamers won't last long to play them. Even for animators, news about gamers imitating violent scenes or indications of the brutal effects of playing games on gamers is a very shocking reality and beyond the capacity of the animators to explain.

In the case of addiction, animators also do not include addiction as the target of the product's achievement. For Irvan, addiction was not created intentionally by the animator, but emerged because of the gamer's own psychological factors. The psychological reaction itself could occurs because of the quality of the online games being played. The quality in question includes several things such as animation visualization, game play scenarios, game concepts, quality at each stage of production to gamer execution of the game.

When an animator or game developer finally applies the principles of animation in game design, as a result, the game will have good quality and "appealing" that allows gamers attracted playing for a long time until it ends up being addicted. Appeal itself is about how an animator makes an animated character interesting [19]. Appeal also means everything that people want to see, quality, charm, simplicity, fun design, communication, and interest [20].

\section{B. The Principle of Animation and The Expected Effect}

In line with what has been mentioned in the method, the data obtained from the interview will serve as a guide to developing a perspective from the literature side. As already mentioned, applying well the principles of animation can have an impact on the quality and gamers interest in the game product. The term 'animation principle' meant by experts refers to the theory of 12 animation principles that are widely used by animators or game developers to create attractive animations [21].

One of the latest literatures that discusses the application of animation principles in game creation is the book Game Anim: Video Game Animation Explained [22]. This book which authored by Jonathan Cooper, a world-class video game animator from Scotland, reinterprets 12 animation principles introduced by Disney animators, Frank Thomas and Ollie Johnston (1995) - which are now widely used as fundamental principles in animation creation.

In brief, Cooper's interpretation of the video game animation perspective is written as follows:
- Squash and Stretch: The reasonableness and flexibility of the shape changing of a character or object when moving in one direction, stopping, or when impacting another object, without reducing or changing the volume of the character.

- Staging: Composing the camera, lighting, and characters so that gamers focus on the scene or message presented in the video.

- Anticipation: Moves the character makes just before performing the core movement.

- Straight Ahead and Pose to Pose: Details of a character's movements in frames per second and the character's core movement poses.

- Follow-Through and Overlapping Action: How the various parts that stick to the character behave when the character moves because of the difference in weight and flexibility of the part with the character's weight, also because of the influence of the character's movement speed.

- Slow in and Slow Out: The fast or slow character action tempo at the beginning and end of the movement. Changes in the direction and speed of movement will be different depending on the type and weight of the character, as well as the direction and distance it travels.

- Arcs: The pivotal movement of a character's limbs forming an imaginary arc

- Secondary Action: Small movements or expression that support the character's main movements to provide detail and emphasis on the character's actions.

- Appeal: Character charisma must be visualized in accordance with the character of the figure you want to portray.

- Timing: The speed of movement of the character must be able to describe the weight and strength of the character according to the direction and distance of movement

- Exaggeration: Exaggerating the expression or movement of a character compared to natural movements in live action

- Solid Drawing: Characters must appear in dimension. In the design stage, the animator must pay attention to the body mechanism of the character which includes the model of movement, body mass and volume, the appearance of the character from various angles and positions.

In game design, the 12 animation principles above play an important role in generating the natural and hyper-reality of characters, objects and the world in the game, as well as emphasizing the nature, role, and scene of each character or object. By the application of these principles, in addition to achieving quality game animation, the game control mechanism will become more efficient and easier to 
understand. This quality will also present gamers with new stories and experiences that they never get in the real world.

Furthermore, Cooper explained that the animation design process and techniques will continue to develop following the latest technology, where with this development animators will continue to create characters and worlds (animation) that appear more real to entertain players around the world. Cooper also stated that the ultimate goal of quality animated games is where players forget they are in front of a screen, escaping their own physical limitations and instead being transported into our virtual world, assuming their character's identity such that it is "they themselves" (and no longer their avatar) who are in the game.

\section{Animator's Perspective and Brutal CAuse POSSIBILITY}

As far as one can conclude based on experts' opinion and animator perspectives in the literature, the brutal effects of online gaming are an issue that is beyond the scientific reach of an animator. Animation experts explicitly mention their limited capacity to explain the issue, while animators, through their own literature, do not discuss any negative impact on the behavior of gamers who play their game products. But both of them deliver the same speculation that the quality of the game's animation allows gamers to be trapped in addiction and drifted into a virtual world.

What can be explained within the scientific reach of the animators is that the well application of animation principles in game design will produce qualified game products. This quality is expected to bring the entertainment and attract gamers to the game products and become an indicator of game success and consumer satisfaction. Meanwhile, the worst things that can be predicted is just opium. Once again, animators' expected goals are entertainment and to give gamers a new experience that they do not afford in the real world.

Based on the perspective of animators in literature, it can also be analyzed that none of the above principles indicate that animated games are designed to be imitated or at least have the potency to be imitated in the real world. There is only reality that is replicated in virtual form with various artistic touches and modifications to make the reality go 'hyper'.

Therefore, it is only proper if animators emphasize that if animators must be involved in uncovering the brutal effects of playing games, animators must collaborate with experts across other disciplines. With collaboration, the opportunity to dissect the problem becomes even greater. For example, interdisciplinary collaboration between animation and psychology can reveal that opium is a "doorway" to a game addict's evil behavior towards other people or objects, as explained by Reali and Anggraini [23]. Animators admit that games have the potential to cause addiction for gamers, whereas in psychology and medical, as stated by WHO [24], gaming addiction in the long term can cause gamers to be unable to control their gaming habits, prioritizing games over other activities, and not realizing its negative consequences of his habit. In this condition, opium has shifted into a mental disorder because it has disturbed or damaged personal, family, social, work and educational lives. Then, as concluded from
Reza Indragiri Amriel [25], when someone is in a state of mental disorder or a brain work disorder, someone may commit heinous acts to others without empathy or to act sadistically only for his satisfaction. According to social learning theory, this vicious behavior can be inspired by what ones have watched or seen, then replicate it in the real world as a result of the imitation process. Reza also admitted that this behavior output can still be reviewed from various relevant disciplines, not only psychology.

\section{CONCLUSION}

The perspective of animators in discussing the brutal effects of playing games addiction is still limited. The epistemology that guides animators cannot be forced to dissect cases of behavioral disorder due to playing online games. The affordable range the animator's sight can discuss is only up to the issue of how the principles of animation produce quality games and attract gamers which purpose is for entertainment and provide satisfaction and virtual experiences that gamers don't get in the real world. Of these goals, the worst possible animator can admit is addiction. Meanwhile, to reveal the aftereffects of opium to the problem of brutal effects, animators need to work in collaboration with other cross-disciplines.

\section{ACKNOWLEDGMENT}

This paper and the research behind it would not have been possible without the exceptional support of my Chief of Study Program and all my mate in Film and Television Department. I am most thankful for the Dean of Faculty who has provided financial support for the submission process. Special thank goes to Arif Johari, Irvan SP as the animation practitioner and experts and all the recommended qualified respondents who have humbly spare their time to have the discussion, supplying the information and correction to the issue, and keep my paperwork on the track.

\section{REFERENCES}

[1] A. Sudarno, "Kisah Pecandu Game Online, Membunuh Sopir Taksi Online demi Servis Laptop," 2019. [Online]. Retrieved from: https://www.liputan6.com/news/read/4102518/kisah-pecandu-gameonline-membunuh-sopir-taksi-online-demi-servis-laptop

[2] A. Syihabudin, "Direcokin Saat Main Game Online, Suami Bunuh Istri," 2019. [Online]. Retrieved from: https://www.pelitabanten.com/44205/2019/05/16/suami-bunuh-istri/.

[3] A. Suhartono, "Keji, Pria di India Bunuh dan Mutilasi Ayahnya GaraGara Dilarang Main PUBG," 2019. [Online]. Retrieved from: https://www.inews.id/news/internasional/keji-pria-di-india-bunuh-danmutilasi-ayahnya-gara-gara-dilarang-main-pubg.

[4] L. Khairul, "Tak Terima Ditegur Karena Kelamaan Main Game, Keponakan Bunuh Pamannya Sendiri Artikel ini telah tayang di Wartakotalive dengan judul Tak Terima Ditegur Karena Kelamaan Main Game, Keponakan Bunuh Pamannya Sendiri, https://wartakota.tribunnews.com/2019/09/,, 2019. [Online]. Retrieved from: https://wartakota.tribunnews.com/2019/09/29/tak-terima-ditegurkarena-kelamaan-main-game-keponakan-bunuh-pamannya-sendiri.

[5] A. Bima, "Suami ceraikan istri hanya karena game," 2019. [Online]. Retrieved

from: https://today.line.me/id/pc/article/Suami+ceraikan+istri+hanya+karena+ game-WYkNP5

[6] F.A. Fitrazana, "Kecanduan PUBG, Ibu Muda Ingin Ceraikan Suaminya dan Ingin Hidup Bersama Partner Bermain Game Online,” 2019. [Online]. Retrieved

from: 
https://jogja.tribunnews.com/2019/05/20/kecanduan-pubg-ibu-mudaingin-ceraikan-suaminya-dan-ingin-hidup-bersama-partner-bermaingame-online.

[7] N.A. Tifani, "5 Kasus Kecanduan Gim Terekstrem, Ada yang Sampai Bunuh Orang," 2019. [Online]. Retrieved from: https://www.liputan6.com/citizen6/read/3136220/5-kasus-kecanduangim-terekstrem-ada-yang-sampai-bunuh-orang.

[8] A. Mayasari, "Curhat Sedih Wanita Hamil Ditinggal Suami yang Kecanduan Game PUBG," 2019. [Online]. Retrieved from: https://wolipop.detik.com/wedding-news/d-4418697/curhat-sedihwanita-hamil-ditinggal-suami-yang-kecanduan-game-pubg.

[9] F. Adzani, "7 Tindakan Kriminal Mengerikan yang Dilakukan Karena Video Game," 2019. [Online]. Retrieved from: https://hai.grid.id/read/071756588/7-tindakan-kriminal-mengerikanyang-dilakukan-karena-video-game.

[10] Liputan 6 Petang, "Kecanduan Game Online, 5 Pelajar Jual Buku Perpustakaan," 2016. [Online]. Retrieved from: https://www.vidio.com/watch/498764-video-kecanduan-game-online-5pelajar-jual-buku-perpustakaan.

[11] Sukoco, "Siswa SD Kecanduan Game Online hingga 4 Bulan Bolos Sekolah, Nenek: Bangunnya Sore, Tidur Subuh," 2019. [Online]. Retrieved

from: https://regional.kompas.com/read/2019/11/21/09431731/siswa-sdkecanduan-game-online-hingga-4-bulan-bolos-sekolah-nenekbangunnya?page $=$ all.

[12] F. Ramadhanny, "8 Fakta Soal Kecanduan Game, Nomor 7 Penting Banget," 2019. [Online]. Retrieved from: https://inet.detik.com/gamesnews/d-4775208/8-fakta-soal-kecanduan-game-nomor-7-penting-banget.

[13] KumparanTECH, "Demi Bebas dari Kecanduan Game, Seorang Remaja Coba Bunuh Diri," KumparanTech, 2018. [Online]. Retrieved from https://kumparan.com/kumparantech/demi-bebas-dari-kecanduan-gameseorang-remaja-coba-bunuh-diri-27431110790557757.
[14] G.S. Putri, "WHO Resmi Tetapkan Kecanduan Game Sebagai Gangguan Mental," $2018 . \quad$ [Online]. Retrieved from: https://sains.kompas.com/read/2018/06/19/192900123/who-resmitetapkan-kecanduan-game-sebagai-gangguan-mental.

[15] A.E. Musthafa, "Pengaruh Intensitas Bermain Game Online dan Pengawasan Orang Tua Terhadap Perilaku Agresif Anak," Universitas Diponegoro Semarang, 2015.

[16] N.I. Siregar, "Pengaruh Perilaku Bermain Video Game Berunsur Kekerasan terhadap Perilaku Agresi Remaja," Institut Pertanian Bogor, 2015.

[17] I. Gunawan, Metode penelitian kualitatif. Jakarta: Bumi Aksara, 2013.

[18] P. Tharenou, R. Donohue, and B. Cooper, Management Research Methode. Cambridge: Cambridge University Press, 2007.

[19] R. Khairunnisah, Analisa \& Perancangan Media Pembelajaran Tentang Komponen Perangkat Keras Komputer Berbasis Animasi 3d. Other Thesis, Politeknik Negeri Sriwijaya. Politeknik Negeri Sriwijaya, 2019.

[20] F. Thomas and O. Johnston, The Illusion of Life: Disney Animation. New York: Disney Edition, 1995.

[21] Z.R. Pintero, "pengaplikasian 12 prinsip animasi disney dan motion capture dalam animasi 'gob and friends," Jurnal Seni Rupa, vol. 6, no. 2, 2016.

[22] J. Cooper, Game Anim: Video Game Animation Explained. London \& Newyork: CRC Press tailor and francis group, 2019.

[23] C. Reali and Y.D. Anggraini, "Pengaruh Game Kekerasan Terhadap Peilaku Agresif Anak," J. Pendidik. PAUD, vol. 1, no. 1, 2016.

[24] G. Humphreys, "Sharpening the focus on gaming disorder," Bulletin of the World Health Organization, vol. 97, no. 6, pp. 382-383, 2019.

[25] KompasTV, "Remaja 15 Tahun Tega Bunuh Balita, Apa Yang Salah?," Indonesia, 2020. [Online]. Retrieved from: https://www.youtube.com/watch?v=2jX0eaee0Eg 